\title{
Resource Orientation in Managing Changes in Healthcare Organizations-Research Results
}

\author{
Joanna Jasińska ${ }^{1 *}$ and Dr hab ${ }^{2}$ \\ ${ }^{1}$ University of Social, Computer \& Medicine Science, Poland \\ ${ }^{2}$ University of Social Sciences Computer Science and Medicine, Vice-Rector for Education and Development, Poland \\ *Corresponding author: Joanna Jasińska, University of Social, Computer \& Medicine Science, Poland
}

\begin{abstract}
ARTICLE INFO
Received: 豐 January 16, 2020

Published: 慧 January 24, 2020

Citation: Joanna Jasińska, Dr hab. Resource Orientation in Managing Changes in Healthcare Organizations-Research Results. Biomed J Sci \& Tech Res 24(5)-2020. BJSTR. MS.ID.004123.
\end{abstract}

\section{ABSTRACT}

The article indicates the use of a resource approach in managing changes in healthcare organizations. The first part presents theoretical considerations underlying the empirical research. The second part of the work presents the results of own research and an attempt to answer the research questions posed:

a) whether the resource approach (RBV) is dominant in the decision-making process in the process of managing change in healthcare organizations?

b) Is the level of utilization of the resource approach in the process of change management in change management in healthcare organizations increasing along with the increasing dynamics of changes in the environment of these organizations?

Keywords: Resource-Based View; Health Care Organization; Change Management; Change

\section{Introduction}

In the face of growing competition in the healthcare sector, organizations operating in it are forced to look for new development opportunities, especially in connection with the growing expectations as to the quality of medical services provided and the efficiency of the use of entrusted resources, especially public funds. As S. Sharma and H. Vredenburg note, in conditions of intense competition and rapid changes in a given market segment, resource-based strategies can be an effective solution [1]. This leads to the conclusion that resource-based company view (RBV) can be used to manage change in healthcare organizations, which focuses managers' attention on assessing the strategic potential of organizational resources. What can be used in the process of effective and efficient change management and building a new strategy for the organization of medical services. The purpose of this article is to present research findings on the use of a resourcebased approach in managing change in healthcare organizations.

\section{A Resource Approach in Managing A Public Organization}

The beginnings of the Resource-Based View (RBV) date back to the 1980s. Above all, previous analyzes of distinctive competences, the Ricardian disability theory and E. Penrose's work have made a significant contribution to building RRV foundations, but the research of B. Wernerfelt and RP Rumelt was a milestone in the development of the resource approach, and J Barney [2]. In terms of resource school, achieving lasting competitive advantage and organizational success is possible thanks to the use of the organization's strategic resources, i.e. resources that meet the socalled VRIN condition, i.e. they are characterized by strategic value (V - Valuable), rarity (R - Rare), non-imitability (I - In-imitable) and lack of substitutes (N - Non-substitutable) [3]. Resources that have the indicated characteristics have the potential to build a lasting competitive advantage of the organization and should become the foundation for developing the organization's change strategy. As J. Barney emphasizes, RBV is not a theory about individual resources of the organization, because it emphasizes the attributes of resources, which may result in gaining a competitive advantage [4].

Therefore, competitive advantage should be understood as creating greater value for the client, greater added value than other organizations operating in the sector. The development of the resource school is closely related to the growing turbulence of the 
external environment, because due to its unpredictability, it is the resources and competences of the organization that provide a more stable basis for generating change strategies [5]. In Polish literature on the subject, the resource approach is particularly considered in the works of R. Krupski, in which it is the basis for building flexible change strategies that allow for quick adaptation to dynamic transformations of the environment [6]. In addition, it is the starting point for planning key competences in the face of increasing turbulence in the environment. A. Koźmiński emphasizes the importance of organizational resources in the conditions of "generalized uncertainty", i.e. the unpredictability of external and internal environment [7]. The organization should strive to accumulate potential, ability to act in unpredictable situations, and this is enabled by its reserves of free resources, especially intangible.

The environment of medical organizations is turbulent, which hinders the process of managing change, making decisions, and adversely affecting organizations. Therefore, in the author's opinion, it seems appropriate to use the resource approach more broadly in the management of medical organizations [8]. The assessment of the environment of medical entities based on two parameters - the unpredictability of change management and the complexity of the environment - indicates that the environment of health care entities is a turbulent environment. They are characterized by a high degree of unpredictability of changes and a high degree of complexity [9]. The high degree of unpredictability is influenced by a multitude of factors generating changes in the environment of the organization, including in particular the politicization in the conditions of Polish healthcare organizations, which results in unpredictability of changes both in the system seen as a whole and in individual medical facilities. In addition, changes in the environment of medical entities are also generated by technological, social and financial factors [10]. The complexity of the environment of healthcare organizations is due to the large number of stakeholders / patients directly or indirectly affecting the organization's activities. Previous studies of the resource concept in healthcare organizations mainly referred to the possibility of using a specific resource in the organization's activities.

However, it should be assumed that the organization adopts a resource approach philosophy. The research covered areas such as: conditions for carrying out changes in the organization of health care, abilities and competences of organization employees, organizational resources, employee knowledge, and innovations as sources of creating organization value [11]. As noted in their work P. G. Klein, A. M. McGahan, J. T. Mahoney, Ch. N. Pitelis, in the management literature, not much space is devoted to the resource concept, because it focuses on resources, or added value to the system. In addition, it is the same in both public and commercial organization management, and in public management the main focus is on the organization's performance [12]. This approach reduces the RBV only to analyzing the resources of the organization and overlooks the most important issue that resources recognized as strategic by definition can translate into better health organization results. Thus, the resource concept in the conditions of operation of health care organizations does not differ as to the main assumptions from the arrangements related to the commercial sector. It is emphasized, however, that health care organizations have the possibility of obtaining resources also using coercive measures, and the competition between them is more focused on gaining an advantage in the area of efficient use of resources and, as a result, obtaining a larger pool of limited public funds [13].

Identifying, using and developing valuable, rare, unlimited resources of healthcare organizations will allow you to more effectively achieve the organization's goals. At the same time, it should be noted that the overriding goal of healthcare organizations is to create public value by fulfilling the organization's mission and fulfilling the electoral mandate, thus creating value for stakeholders / patients. Without constant attention to the quality of medical services and the usefulness of their resources in the face of the growing dynamics of the environment, healthcare organizations are not able to achieve their goals, strengthen their values for patients and respond effectively to changes occurring in the external environment [14]. The above considerations of the author justify the use of a resource approach to the management of healthcare organizations. J. M. Bryson, F. Acermann and C. Eden also propose such an approach to change management in medical organizations, who claim that the basis for building a strategy for organizing healthcare should be recognized expectations of stakeholders / patients.

In addition, the identification of the organization's resources to create the greatest value for the stakeholder [15]. The resource approach has also found application in the model for assessing the competitiveness of public hospitals proposed by V. Eiriz, N. Barbos and J. Figueiredo. The guidelines they propose for change management are contained in three areas: analysis of organizational resources according to the resource concept of VRIN, analysis of strategies for planned changes in organization and results of operations being the starting point for planned changes.

\section{Orientation of Resources in the Process of Change Management in A Health Care Organization - Test Results}

The presented considerations prompted the author to design research aimed at identifying resource orientation in healthcare organizations. Public health entities were selected as the research entity, which was dictated by the growing turbulence of the environment in the healthcare sector, in which new legal regulations and market realities often complicate the process of building an effective strategy for changes that allow meeting the expectations of stakeholders / patients. Literature studies have led to two research questions:

a) Is the resource approach (RBV) dominant in the decisionmaking process in managing changes in public health care organizations? 
b) Does the level of utilization of the resource approach in the decision-making process in managing changes in public healthcare organizations increase with the increasing dynamics of the external environment of these organizations?

As already indicated, the existing research on the resource concept in healthcare organizations mainly referred to the possibility of using a specific resource in the organization's operations, assuming that the organization adopts the philosophy of the resource approach. It should be noted, however, that in the literature in the field of change management there is a shortage of research identifying the resource orientation represented by organizations. Therefore, it seems reasonable to strive to fill the indicated deficiencies, using indirect tools to determine the resource orientation of the organization, developed in relation to health care organizations [16]. The research method adopted to achieve the above objectives was quantitative research, for which data was obtained through a survey. To construct the questionnaire, a questionnaire was used to study the assumed resource orientation by R Krupski [17].

The subject of the study were public health care organizations. 87 managers of healthcare institutions constituted the research sample [18]. The survey was conducted in March 2019. It had the character of a survey, and the sample size and selection method do not authorize to generalize the results to the entire population. The presented results are only a picture of the situation in the studied medicinal entities and provide guidelines for the design of further research in the indicated area. Table 1 presents the structure of respondents. The majority of the surveyed population were employees of large units, employing over 250 employees and operating on the health care market for over 20 years. The financial situation of the units in which the respondents work was assessed as mostly good or average. Due to the job position, $30 \%$ of respondents consisted of directors / presidents or deputy directors / presidents of medical entities; $43 \%$ of respondents are administrative employees with managerial functions.

Table 1: Characteristics of the study population.

\begin{tabular}{|c|c|c|}
\hline \multicolumn{3}{|c|}{ Unit Size } \\
\hline below 50 & Population & Percentage \\
\hline $50-249$ & 6 & $6,9 \%$ \\
\hline $250-999$ & 36 & $29,9 \%$ \\
\hline 1000 and more & 19 & $41,4 \%$ \\
\hline Total & 87 & $21,8 \%$ \\
\hline & 8 & $100,0 \%$ \\
\hline 0kres istnienia organizacji \\
\hline from 5 years & Population & Percentage \\
\hline 6-10 years & 15 & $2,3 \%$ \\
\hline $11-20$ years & 62 & $17,2 \%$ \\
\hline above 20 years & 87 & $71,3 \%$ \\
\hline Total & & $100,0 \%$ \\
\hline
\end{tabular}

\begin{tabular}{|c|c|c|}
\hline \multicolumn{3}{|c|}{ Sytuacja finansowa organizacji } \\
\hline & Population & Percentage \\
\hline very good & 12 & $13,8 \%$ \\
\hline good & 30 & $34,5 \%$ \\
\hline average & 23 & $26,4 \%$ \\
\hline bad & 11 & $12,6 \%$ \\
\hline very angry & 11 & $12,6 \%$ \\
\hline Total & 87 & $100,0 \%$ \\
\hline \multicolumn{3}{|c|}{ Stanowisko respondenta } \\
\hline Doctor & 7 & Percentage \\
\hline Nurse & 17 & $8,0 \%$ \\
\hline Director / Deputy & 26 & $19,5 \%$ \\
\hline Director & 37 & $29,9 \%$ \\
\hline Administration & 87 & $42,5 \%$ \\
\hline Total & $100,0 \%$ \\
\hline
\end{tabular}

Source: Own Research: The identification of the resource orientation dominant in the examined healthcare organizations was based on the time horizons of thinking and decision making in the system: resource orientation and market orientation. The adopted orientation classification is based on the description of the resources of the organization presented by B. de Witt and R. Meyer. Due to the permissible volume of this article, the research part focuses on the perspective of making changes management perspective in the context of making decisions about the types of organizational changes in healthcare institutions, and the measure of planned changes is the time perspective of decisions made by managers. For the time horizon of decisions related to the external environment of healthcare organizations (Table 2), the average time for public medical entities is 2.89 years. Thus, when deciding, the manager thinks about its consequences in the perspective of about 3 years. For markets that are the most representative element of the environment, this perspective is 2.98 years. It is slightly higher for suppliers - 3.14 years, which may result from the possibility of regulating some issues in the contracts signed, and thus partly limiting the variability of this element of the environment.

Table 2: Decisions related to the environment in years (number of responses, average).

\begin{tabular}{|c|c|c|c|c|c|c|c|}
\hline & $<\mathbf{1}$ & $\mathbf{1 - 3}$ & $\mathbf{3 - 5}$ & $\mathbf{5 - 1 0}$ & $\mathbf{> 1 0}$ & $\mathbf{N}$ & Average \\
\hline products & 24 & 37 & 18 & 4 & 4 & 87 & 2,74 \\
\hline markets & 13 & 44 & 20 & 8 & 2 & 87 & 2,98 \\
\hline competitors & 20 & 42 & 11 & 8 & 6 & $\mathbf{8 7}$ & $\mathbf{3 , 1 4}$ \\
\hline provider & 25 & 40 & 16 & 4 & 2 & $\mathbf{8 7}$ & $\mathbf{3 , 1 4}$ \\
\hline other (e.g. offices) & 23 & 34 & 19 & 4 & 7 & $\mathbf{8 7}$ & $\mathbf{2 , 4 3}$ \\
\hline aggregated & 105 & 197 & 84 & 28 & 21 & $\mathbf{4 3 5}$ & $\mathbf{2 , 8 9}$ \\
\hline
\end{tabular}

Source: Own Research: In the case of resource orientation (Table 3), the average time horizon for making decisions in managing changes in public healthcare organizations is 3.80 years. 
The managers show the longest decision time horizon for location decisions - 5.44 years. In the case of location, such a long time perspective may result from the very period needed to implement the investment, e.g. reconstruction of the facility, which requires time not only for purely construction works, but also covers the entire investment process, starting from the original vision, by completing all formalities, until to obtain the necessary operating permits. A relatively extensive time horizon of decisions made was also indicated for building the image of the changed organization of healthcare. This is due to the fact that it takes a lot of time to "build" the indicated resource and it does not undergo quick and easy changes. The shortest time horizon of decisions in managing health care changes was indicated for decisions on sources of financing, which may be due to the fact that this is a very variable element. In addition, the financing situation of public healthcare entities in Poland does not allow decisions to be made in the long term.

Table 3: Decision making on resources in years (number of responses, average).

\begin{tabular}{|c|c|c|c|c|c|c|c|}
\hline The Resource-Based orientation & $<1$ & $1-3$ & 3-5 & $5-10$ & $>10$ & $\mathbf{N}$ & Average \\
\hline Knowledge & 13 & 28 & 28 & 13 & 5 & 87 & 3,84 \\
\hline $\begin{array}{l}\text { Attitudes, employee behavior and other elements of } \\
\text { organizational culture }\end{array}$ & 19 & 32 & 21 & 11 & 4 & 87 & 3,33 \\
\hline Formalized relations with the environment & 13 & 34 & 27 & 9 & 4 & 87 & 3,45 \\
\hline Informal relations with the environment & 17 & 27 & 30 & 8 & 5 & 87 & 3,51 \\
\hline Medical technologies & 9 & 30 & 33 & 12 & 3 & 87 & 3,72 \\
\hline Information Technology & 13 & 27 & 29 & 15 & 3 & 87 & 3,75 \\
\hline Natural resources & 17 & 31 & 22 & 13 & 4 & 87 & 3,52 \\
\hline Location & 4 & 25 & 24 & 20 & 14 & 87 & 5,44 \\
\hline The image of the organization & 13 & 27 & 19 & 16 & 12 & 87 & 4,67 \\
\hline Sources of funding & 19 & 31 & 25 & 10 & 2 & 87 & 3,12 \\
\hline Routines, internal solutions & 24 & 27 & 18 & 12 & 6 & 87 & 3,48 \\
\hline Aggregated & 161 & 319 & 276 & 139 & 62 & 957 & 3,80 \\
\hline
\end{tabular}

Source: Own Research: Based on the average time horizons of decision making in the management of healthcare organizations, we can point to the dominant resource orientation (Table 4). The analysis of the data contained in the table below indicates the resource orientation as the dominant among public health entities. Both in the perspective of thinking and making decisions, the time horizon is definitely longer than for positional (not resource) orientation. The dominance of resource orientation may result from the growing dynamics of changes in the environment of healthcare organizations, in which conditions it seems appropriate to turn towards the interior of the organization as more predictable than its environment.

Table 4: Comparison of resource and positional (non-resource) orientation. in terms of medium thinking and planning horizons

\begin{tabular}{|c|c|c|}
\hline Orientation & $\begin{array}{c}\text { Resource } \\
\text { Orientation }\end{array}$ & $\begin{array}{c}\text { Positional } \\
\text { orientation }\end{array}$ \\
\hline Thinking time horizon & 4,54 & 3,31 \\
\hline Decision time horizon & 3,80 & 2,89 \\
\hline
\end{tabular}

Source: Own Research: In the next step, the surveyed healthcare organizations were divided into three categories depending on their strategic orientation, which was assessed on the basis of average time horizons for thinking and making change management decisions. If the time horizon was longer for the environment than for resources, the organization represented positional orientation, if the time horizon was longer for resources, then the organizations were classified as organizations with a resource orientation. A third category was identified - balanced orientation, when the difference between time horizons was small (less than half a year). The results of the study in Table 5 indicate that the vast majority of the analyzed health care organizations represented resource orientation, both in terms of thinking and decision making, as well as in aggregate analysis.

Table 5: Orientation of change management strategies for public healthcare entities.

\begin{tabular}{|c|c|c|c|}
\hline & $\begin{array}{c}\text { The prospect of } \\
\text { thinking }\end{array}$ & $\begin{array}{c}\text { The prospect of } \\
\text { making decisions }\end{array}$ & Collectively \\
\hline $\begin{array}{c}\text { Resource } \\
\text { orientation }\end{array}$ & $52,9 \%$ & $48,3 \%$ & $58,6 \%$ \\
\hline $\begin{array}{c}\text { Positional } \\
\text { orientation }\end{array}$ & $28,7 \%$ & $29,9 \%$ & $24,1 \%$ \\
\hline $\begin{array}{c}\text { Balanced } \\
\text { orientation }\end{array}$ & $18,4 \%$ & $21,8 \%$ & $17,2 \%$ \\
\hline Aggregated & $100,0 \%$ & $100,0 \%$ & $100,0 \%$ \\
\hline
\end{tabular}

Source: Own Research: An important element of the research, in addition to identifying the dominant strategic orientation, was also to examine whether, as the turbulence of the external environment increases, the surveyed organizations adopt a resource orientation. Literature studies indicate that focusing on 
the interior of the organization, its resources and competences is crucial in the conditions of increasing dynamics of the external environment. In the conducted research, the environment of healthcare organizations was considered in three areas - market, technology and social. Each of the areas was assessed in terms of its dynamics - as a stable environment, predictable variables and unpredictable variables. In the case of a market environment, being the best representative of the environment of healthcare organizations. Figure 1 shows that with the increasing variability of the external environment, the percentage of healthcare organizations adopting resource orientation is increasing, while the percentage of positional orientation is decreasing. In the case of the growing dynamics of the market environment, healthcare organizations focus more on their resources, because it is a predictable and controllable element of the organization.

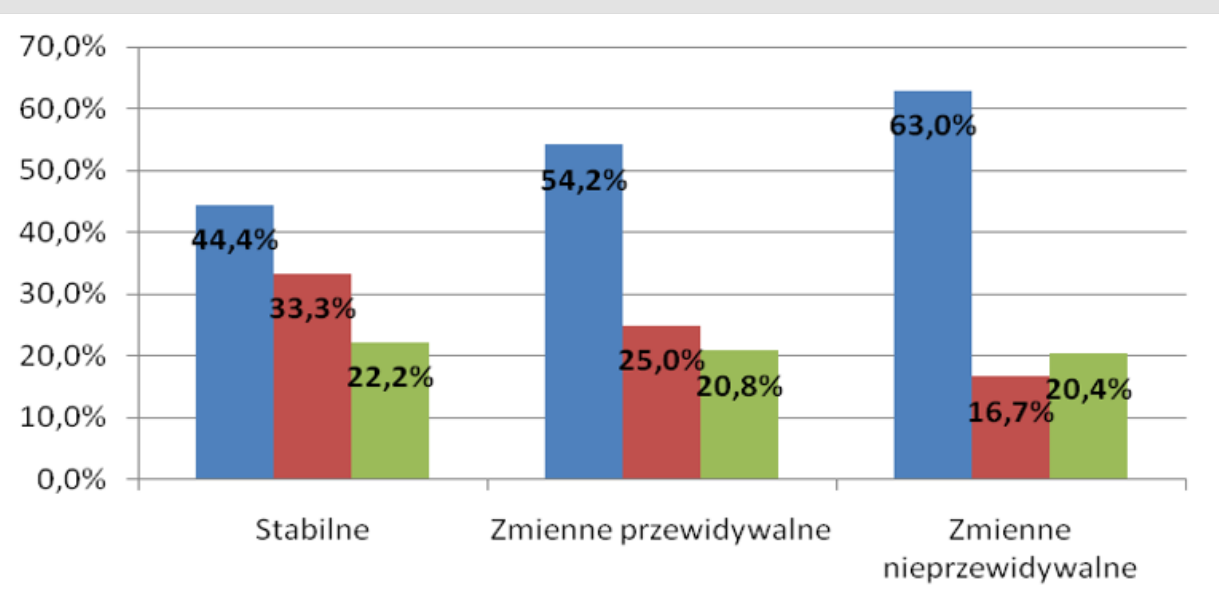

घOrientacja zasobowa Orientacja pozycyjna @ Orientacja zrównoważona

Figure 1: Market environment and the strategic orientation of public medical entities.

\section{Conclusion}

The growing turbulence of the external environment of health care organizations forces them to look inside these organizations to seek competitive advantage. Building the organization's strategy in accordance with the concept of a resource school, i.e. identifying and using as well as developing strategic and valuable resources of health care entities. The activities are to serve and contribute to creating higher value for patients of healthcare organizations. The conducted research showed that in public healthcare entities in the decision-making process the resource approach dominates, which allows medical organizations to effectively manage changes in the face of the growing turbulence of the external environment in which they are forced to function. Both when thinking about resources and making decisions, managers show an average time horizon, higher than when thinking or making decisions about the external environment.

In addition, together with the increasing dynamics of changes, resource orientation becomes dominant in the examined health care organizations at the expense of positional orientation. Basing the strategy on strategically valuable resource potential of the organization should translate into creating higher value for patients of healthcare organizations. The development of public healthcare entities depends on meeting the expectations of key stakeholders. In addition, the use of the resource concept can contribute to more effective change management and use of existing resources, as well as building new resources, and will meet the current and future expectations of patients in healthcare organizations on an ongoing basis.

\section{References}

1. Barney J (2011) Firm Resources and Sustained Competitive Advantage. Journal of Management 17: 99-120.

2. Barney JB, Clark DN (2017) Resource-Based Theory. Creating and Sustaining Competitive Advantage. Oxford University Press, New York, USA

3. Boyne G, Meier K (2019) Environmental turbulence, organizational stability and public service performance. Administration Society 40(8): 799-824.

4. Bryson JM, Acermann F, Eden C (2017) Putting the Resource-Based View of Strategy and Distinctive Competencies to Work in Public Organizations. Public Administration Review pp. 702-117.

5. Burton R, Obel B, DeSanctis G (2014) Organizational Design. A step-bystep approach. Cambridge University Press, New York, USA.

6. Eiriza V, Barbosa N, Figueiredo J (2015) A Conceptual Framework to Analyse Hospital Competitiveness. The Service Industries Journal 30(3): 437-448.

7. Frączkiewicz Wronka A (2016) Frączkiewicz Wronka A (2016) Resource approach in public organization management - stakeholder perspective, In: R Krupski (Ed.), Development of a strategic management resource school. Ed. Wałbrzych College of Management and Entrepreneurship, Wałbrzych.

8. Frączkiewicz Wronka A, Szymaniec K (2014) Model interesariuszy w zarządzaniu zmianą w szpitalach, [w:] Ł. Sułkowski, R. Seliga (red.): Kulturowe determinanty zarządzania szpitalami w Polsce. Difin, Warszawa. 
9. Grant R (2013) Strategic planning in a turbulent environment: Evidence from the oil majors. Strategic Management Journal 24: 491-517.

10. Klein PG, Mc Gahan AM, Mahoney JT, Pitelis Ch N (2014) Resources, Capabilities, and Routines in Public Organization. Working Papers, University of Illinois, College of Business.

11. Koźmiński A (2015) Zarządzanie w warunkach niepewności. Podręcznik dla zaawansowanych. Wydawnictwo Naukowe PWN, Warszawa.

12. Krupski R (2014) Orientacja zasobowa w badaniach empirycznych Identyfikacja horyzontu planowania rynkowych i zasobowych wielkości planistycznych. Wałbrzyska Wyższa Szkoła Zarządzania i Przedsiębiorczości, Wałbrzych.

13. Matthews J, Shulman A (2016) Competitive advantage in Public sector organizations: Explaining the public good/sustainable competitive advantage paradox. Journal of Business Research 58(2): 232-240.

14. Romanowska M (2014) Metody badania strategii, In: R Krupski (Ed.), Metody badań problemów zarządzania strategicznego. Prace Naukowe

\section{ISSN: 2574-1241}

DOI: $10.26717 /$ BJSTR.2020.24.004123

Joanna Jasińska. Biomed J Sci \& Tech Res

(C) This work is licensed under Creative

Submission Link: https://biomedres.us/submit-manuscript.php
Wałbrzyskiej Wyższej Szkoły Zarządzania i Przedsiębiorczości, tom 17, Wałbrzych.

15. Sharma S, Vredenburg H (2014) Proactive corporate environmental strategy and the development of competitively valuable organizational capabilities. Strategic Management Journal 79(8): 729-753.

16. Szymaniec K (2013) Orientacja zasobowa w zarządzania organizacją publiczną-identyfikacja strategicznych zasobów organizacji ochrony zdrowia, I Rudawska, E Urbańczyk (Eds.), Opieka zdrowotna. Zagadnienia ekonomiczne. Difin, Szczecin.

17. Szymaniec K (2015) Wykorzystanie podejścia zasobowego (RBV) do kształtowania relacji z interesariuszami i zarządzania organizacją publiczną, [w:] A. Frączkiewicz-Wronka (red.): Wykorzystanie analizy interesariuszy w zarządzaniu organizacją zdrowotną. Wyd. Śląsk, Katowice s. 68-88.

18. De Wit B, Meyer R (2017) Synteza strategii. Tworzenie przewagi konkurencyjnej przez analizowanie paradoksów. Polskie Wydawnictwo Ekonomiczne, Warszawa.

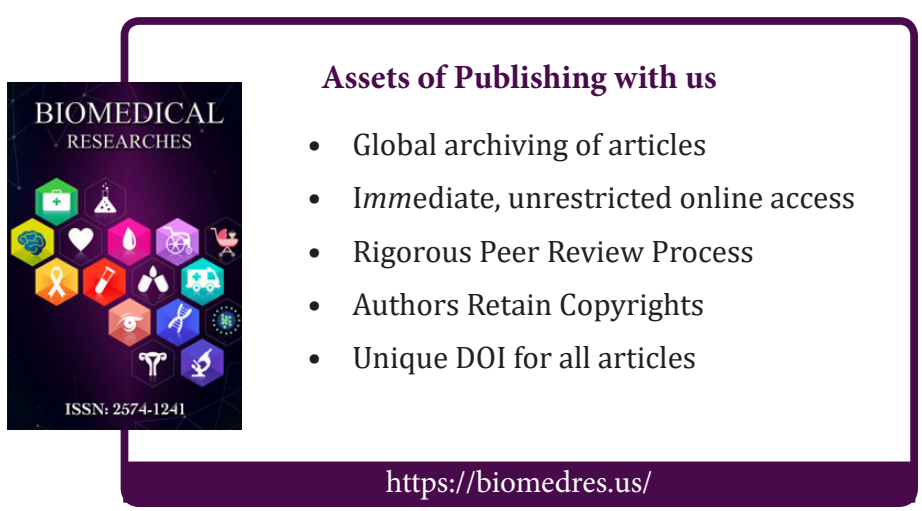

